History, Violence and Collective Memory:

Implications for Mental Health in Ecuador

\author{
Accepted by Transcultural Psychiatry \\ Manuel Capella, Sushrut Jadhav $\uparrow$ and Joanna Moncrieff \\ Division of Psychiatry, University College London
}

Date accepted 15 April 2017

tCorrespondence: Sushrut Jadhav, Division of Psychiatry, University College London, London W1T 7NF, United Kingdom

E-mail: s.jadhav@ucl.ac.uk 


\begin{abstract}
National histories of violence shape experiences of suffering and professional responses. In Ecuador, mental health literature addressing this crucial issue is scarce and little debated. In contrast, local psychiatrists and psychologists within the country face contemporary challenges that are deeply rooted in a violent colonial past and the perpetuation of its fundamental ethos. This paper critically reviews relevant literature on collective memory and historical trauma, and focuses on Ecuador as a case study on how to incorporate history into modern mental health challenges. The discussion poses key questions and outlines possible ways for Ecuador to address the link between history and mental health, including insights from countries that have struggled with their violent pasts. This paper contributes to ongoing international debate on the role of cultural history in mental health with implications for social scientists and practising clinicians in former colonised nations.
\end{abstract}




\section{History, Violence and Collective Memory: Implications for Mental Health in Ecuador}

A meeting is taking place between State representatives and staff from a psychology training institution in the Ecuadorian city of Guayaquil. Civil servants discuss a recent case of vandalism within a so-called “marginal-urban area," and request urgent help from psychologists. In the words of a State functionary, people living in this peripheral place are "gente humilde" (poor people); around "80-90 per cent" belong to the "Afro community"; they were "criminal people, in many cases," with a "personality that tends to aggression," living a "culture of violence." Faculty members stressed the analytical and practical complexity of the situation, including safety issues for potential students and staff who might enter the zone. State functionaries are shocked as they hear how, last year, a female psychology student managed to escape after being threatened with rape at gunpoint within a marginalised zone. Issues of domestic violence and substance abuse are a frequent concern of locals and professionals alike. Classist, racist and sexist comments (commonly, using humour) are extremely frequent not only in the streets and media, but in my informal interactions within spaces where psychologists and psychiatrists are trained. (Vignette from field notes, MC, 2015)

This vignette stresses a little-contested fact: direct, structural and cultural violence is a persistent feature of life for those whom mental health services are intended to help (Galtung, 2003). However, there is a different, less consensual issue 
that poses key theoretical and practical challenges: what is the place of history in the analysis of, and interventions around, violence addressed by mental health professionals? Although academic discussions on these issues are documented in the international landscape (Kirmayer, Gone, \& Moses, 2014; Summerfield, 2001), they are scarce within Ecuadorian mental health and do not resonate to the extent one would expect in a postcolonial nation that - as all of Latin America- is "stained by conquest and exploitation" (Mari, Saraceno, Rodriguez, \& Levav, 2007, p. 1514). This paper examines the link between violent histories and contemporary mental health challenges, in order to discuss how Ecuador and other postcolonial nations might incorporate history into modern conceptualizations and interventions.

History matters. In postcolonial Latin American nations, meanings around power, health and illness "are informed by the complex dialectic of their histories" (Silverblatt, 1983, p. 425), which are themselves embedded in the history of global capitalism (Marx, 1977). Violence is polysemic and context-dependant (Moreno, 2009; Stewart \& Strathern, 2002). Still, it is reasonable to talk about a violent Latin American history anchored in material and symbolic colonial dispossession and an exploitative fascination with a non-European "inferior" alterity, which constructed overlapping meanings around culture, race and gender (Young, 1995). Such power relationships between classes, genders and race-ethnicities persist in contemporary Ecuador, through myths, symbols and everyday social interactions (Weismantel, 2001). Local professionals need to be familiar with such crucial historical and cultural dimensions. If they do not engage in nuanced analysis and discussions around them, they will fail to appreciate the challenges faced by contemporary communities, and be limited in their understanding of the cultural construction of health and illness (Napier et al., 2014). 
History permeates into the present through structural inequalities based on income and race-ethnicity. A recent official report on gendered violence in Ecuador is enlightening (Consejo Nacional para la Igualdad de Género, 2014). It suggests that although all Ecuadorian women suffer from alarming levels of violence - six out of ten of them report to be victims - African-Ecuadorian and indigenous women are the most affected. The reported "triggers" of domestic violence tend to be substance abuse (37.4\%), jealousy (47.4\%); unfaithful male partners (37.2\%) and economic problems (36.4\%). All of these variables are culturally and historically constructed. The most frequently reported consequences are 'sadness or depression' (76.7\%) and 'anguish or fear' $(56.7 \%)$. Education seems to be a protective factor, but it is white women usually from higher socioeconomic strata - who have greater access to symbolic and material resources (p.34). Mental health epidemiology (Ministerio de Salud Pública, 2014) ${ }^{\mathrm{i}}$ is yet to explore the role of structural and cultural factors, even for the most prevalent diagnoses, which for 2012 were substance abuse (29\%) and mood disorders (28.1\%). Clinical experience suggests a link between suffering and local cultural features around income, race-ethnicity and gender.

Culturally grounded experiences of mental suffering in Ecuador are clearly shaped by contemporary influences, including poverty, drug trafficking, or direct gendered violence (Cruza-Guet, Spokane, Leon-Andrade, \& Borja, 2009). However, they are also the result of structural and cultural violence constructed through centuries of power asymmetries (Vega, 2012). This is why contemporary Ecuadorian State is constitutionally anticolonial, and its citizens are the heirs of all social and liberating struggles against all forms of domination and colonialism (Const., 2008, p. 8) ${ }^{\mathrm{ii}}$. Although colonialism poses a theoretical challenge (Penson, 2014), it needs to be understood as a broader determinant of health (Czyzewski, 2011), shaping current 
mental suffering. This view is necessary because it is argued that "history and its erasure are often embodied as bad health outcomes", which "is especially true among the vulnerable" (Farmer, 2004, p. 315). The Ecuadorian colonial period was historically complex, and cannot be blamed for every single contemporary problem. However, some Ecuadorian authors had argued that the

struggle to be less Indian ${ }^{\text {iii }}$ and black and more white, to see oneself as of higher status and with economic privilege, as well as to define one's worth based on the control and exploitation of others are all indebted to the colonial legacy. (Benavides, 2006, p. 61)

This paper examines the relationship of violent histories with current mental health challenges through a critical literature review, focusing on Ecuador as a case study. It presents a brief- historical overview of Ecuador, and then situates this within the international discourse on collective memory and historical trauma. The analysis suggests ways that history can be incorporated into the mental health field, while at the same time, integrating the case of Ecuador history within ongoing international debates on colonialism and mental health.

\section{Methods}

Search for literature comprised two stages, both conducted through the $U C L$ Explore platform, which covers textbook catalogues and most sources from major academic databases (Web of Science Core Collection; Scopus; Anthropology Index Online; IBSS; ASSIA; PsychInfo, JSTOR, ERIC, MEDLINE, Pubmed). The search was conducted in two stages as the literature required a focus on local historical as well as more international theoretical publications on collective memory and historical trauma. Stage one included a search (1950 through January 2015) on key terms 
"Ecuador" and "colonial", resulting in 749 hits. Stage two (search from $1992^{\text {iv }}$ through June 2015), deployed the key terms "collective memory" and "historical trauma", resulting in 813 hits. During both stages, additional sources were strategically included, obtained through access to locally published literature in Ecuador, reference tracking, and specific searches in Google Scholar. After dismissing duplicates and non-relevant, a set of sources (in English and Spanish language) on Ecuadorian history and collective memory and historical trauma were reviewed.

This review is purposive, critical and reflexive. The selected literature was chosen and reviewed based on availability, conceptual relevance and argumentative utility. Results from stage one are presented in the form of a contextualised historical and cultural analysis. This paper 1) is not a comprehensive historiographic review, but an attempt to provide a historical context; 2) relies, mainly, on secondary sources; 3) has a cross-disciplinary focus on culture and mental health, rather than in history; 4) encounters the unavoidable problem of analysing distant experiences of suffering through modern categories; and 5) addresses, primarily, mental health professionals working in Ecuador and other former colonised nations ${ }^{\mathrm{v}}$. The review of literature from stage two is not an end in itself, but the means to put forward a critical argument and propose relevant recommendations. It privileges certain conceptual frameworks (e.g., sociocultural) and cases (e.g. Latin America and similar postcolonial contexts), including illustrative examples from other latitudes. As this paper is authored by mental health professionals from two different post-colonial nations (MC \& SJ; males, Ecuadorian Mestizo and Indian Dalit respectively) and a former colonial country (JM; female, white, United Kingdom), our collaboration allows for a complementary, crosscultural and reflexive perspective. 


\section{History and violence in Ecuador}

Contemporary Ecuador is both diverse and unequal. Most people categorise themselves as mixed raced (Mestizo, 71.9\%) and religious (92\%; of which $80 \%$ are Catholics). Many are poor (25.4\%) or extremely poor (10\%), although equality has improved in recent years (Gini index $=0.455,2015$ ). The economy, however, has recently been impacted by a fall in international oil prices; and by a devastating earthquake in April 2016. Apart from the mestizo (mix-raced) majority, there are other ethnicities, such as the self-categorised montubio (7.4\%), African-Ecuadorian (7.2\%), Indigenous $(7 \%)$ and white $(6.1 \%)$. In Ecuador, many people have a "postcolonial obsession with skin and hair colour" (Roitman, 2009, p. xii), making racism "the most haunting and daunting of Ecuador's colonial specters" (Lane, 2003, p. 89). Even if positivist-oriented studies suggest that Ecuador is a remarkably empathetic nation (Chopik, O'Brien, \& Konrath, 2016), this seems to be only part of the picture, as it clashes with everyday experiences of, for example, racial discrimination.

The history of Ecuador has long been violent. From pre - Hispanic times (circa $10,000 \mathrm{BC}-1534^{\mathrm{vi}}$ ) - including the few decades of Inca ${ }^{\mathrm{vii}}$ colonization of (mainly) the highlands, around 1460 - there were intergroup conflicts (McEwan \& Delgado, 2008), which were hypothesised to be a form of gendered violence (Ubelaker, 2003), as coastal men were reported to "treat their women very badly" (Fernández de Oviedo, 1535, cited by Benavides, 2002, p. 75).

However, it was during the nearly three hundred years of Spanish colonization (1534 - 1822) - especially its initial military stage - where violence emerged at the core of a social structure which dehumanised local indigenous and Africandescendants slaves (brought by the Spanish in 1538), killing or disabling them on a 
mass scale (Ayala Mora, 2008; Lane, 2003). Moreover, epidemic diseases and socioeconomic exploitation "led to the death of millions" (Austin Alchon, 1992, p. 133), with the coastal communities - specially the southern coast - suffering the greatest losses (Newson, 1995). As argued by Fanon (2004), people under colonial oppression might feel they are "attending a real apocalypse" (p. 126). In Ecuadorian land, "disoriented" and "depressed" indigenous mothers even killed their own children regularly (Townsend, 2000, p. 52), while African-descendant slaves were lashed, mutilated, castrated and murdered (Bryant, 2004).

Colonialism involved cultural violence alongside physical oppression. Catholicism and the Spanish language were imposed with systematic cruelty. Ritual practices led by shamans - which not only included the use of alcohol, ayahuasca or coca (Stahl, 1986; Vega, 2012), but specific cross-dressing and homosexual practices in the coast (Benavides, 2002) - were considered abominable devil worshiping by the Spanish (Silverblatt, 1983). The indigenous were stripped of their culture and community organization, while the Church patronised them (Conferencia Episcopal Ecuatoriana, 2001; Ibarra, 1992). By the late colonial era, everyday life was difficult. Non-white poor children were sexually abused in the streets, for example (Milton, 2004). And, just as it is reported today, "drunkenness" was frequent, and distrust or jealousy triggered gendered violence (Borchart de Moreno, 2004, p.141).

The $20^{\text {th }}$ century mestizaje discourse - the idea that most Ecuadorians are or ought to become mestizos - also has its more distant roots in the colonial era. Encomenderos - original Spanish landowners - relied on their collaboration with local indigenous chiefs - or caciques - who were spokesmen for their communities and taxcollectors for the invaders, in exchange for business privileges (Salomon, 1983). 
Caciques "adopted a Hispanicized lifestyle to alienate them from their indigenous subjects" (Salomon, 1983, p. 414). Over time, the mestizo ethnicity emerged, based on intermarriage between Spanish (or their American born descendants, the creole or criollos) with indigenous caciques, or because of sexual violence against women (Powers, 2002). This is how seminal colonial ethnicities gradually consolidated: blancos (white), mestizos, indios (indigenous) and negros (African-Ecuadorians) ${ }^{\text {viii }}$. In current times, however, everyone not appearing white - including numerous mestizos - is subject to racism (Roitman, 2009).

Simon Bolivar - a South American creole - led the war that put an end to Spanish colonialism in the region (by 1820-1822). When Ecuador emerged as an independent Republic (1830), however, the violent colonial footprint was already present, while modern racism emerging from Europe took a prominent role. Progressive milestones aside - the abolition of slavery (1851) and indigenous taxes (1857) - , independence mainly benefited the agenda of the white creole (Ayala Mora, 2008). Women were still abused (Borchart de moreno, 2004; Chaves, 2001). Large rural-urban migrations initiated during colonial days as attempts to escape indigenous taxes continued, consolidating inequalities within major cities - such as Guayaquil (Townsend, 2000) - enabling the dissemination of rural beliefs systems into urban settings.

Racial stereotypes continued. A high school textbook written by a well-known Ecuadorian scholar of the time (Juan León Mera, 1884, cited by Ibarra, 1992) associated the indigenous with "humiliation, shyness and cunning"; the European descendants, in contrast, "retain much of the Spanish character", being "religious, honest, generous and loving of their independence and freedom"; those of mixed race 
moved towards the latter as they became "civilised" (p.257). The feelings of the Ecuadorian poet, Medardo Ángel Silva (1898-1919), who committed suicide in Guayaquil, aged 21, ${ }^{\text {ix }}$ illustrate the internalization of colonial violence within Ecuador at the turn of the $20^{\text {th }}$ century. The following extract is from a private letter he wrote to a friend:

I despair in poverty and I am offended by blackness. Is it curious: I am a man of pure white race. My grandfather was Spanish. It is useless to explain a freak phenomenon of nature. But you must know that in me harbors a pure Iberian heritage. However, I look like a black Moor. And this physical reality, in my country, is a source of shame. But I would not mind as much being the black member of my family, if, in addition, I also were not poor (Romero Castillo, 1970, cited by Benavides, 2006, p. 18).

Racism continued throughout the $20^{\text {th }}$ century. Beck, Mijeski, \& Stark (2011) illustrate how imported ideas by Herbert Spencer inspired local scholars to call "black and mulattos" an uncivilised "servile race", resembling animals, "the child or the savage", and having "bloody and warlike ways" that caused political instability in the country (p.103). An interesting resonance with some of the recent words used by the State functionary cited at the start of this paper, who refers to an "Afro" personality that "tends to aggression".

In Ecuador, such hegemonic values have been - and arguably still are - privileged: to be either white or a white-looking mestizo. This valued goal is not only about skin-colour, but about material and symbolic displacement anchored in cultural-economic asymmetrical power relationships. Since the 1950 s, "the price" the indigenous had to "pay" in order to achieve "social and economic mobility" has been to give up his traditional culture and move to a city" 
(Linke, 1954, p. 59). Today, the ethnic labels montubio (population from the rural coast) or cholo are commonly used in a pejorative ways. The term "cholo" - introduced as a racist insult by the Spanish in the $17^{\text {th }}$ century, with an original meaning close to mongrel dog (Garcilaso de la Vega, 1963) - is "an ambiguous racial marker that denotes a class standing lower than that of a mestizo" (Benavides, 2006, p. 33). It refers to a social position that is "more often defined in cultural or geographical than explicitly racial terms"(Weismantel, 2001, p. 90). In contemporary Ecuador, being called a cholo - or a montubio - is still a common classist and racist insult, despite efforts by both liberal and conservative groups to vindicate and ideologically romantisize such terms (Weismantel, 2001). The historical construction of this contemporary Ecuadorian reality is undeniable, as

The long and violent history of racial oppression is written onto the descendants of Europeans whether we like it or not, for our bodies represent the destruction of other, Indian bodies: those killed in the past, and their absent descendants (Weismantel, 2001, p. 218)

Ecuadorian history is much nuanced than what can be shared in the context of this paper. The country underwent a secularising liberal revolution led by Eloy Alfaro (1895-1912), economic booms based on cocoa (circa 1900) and later bananas (1948), a political effervescence in the 1960s, and military dictatorship and the discovery of oil during the 1970s - a decade that also witnessed the birth of contemporary peripheral, marginalised urban communities (Moser, 2009). During the 1980s, State forces engaged in systematic repression against a marginal left-wing armed group, including torture and extrajudicial executions (Comisión de la Verdad, 2010). By 1999, after decades of neoliberal policies, Ecuador experienced a major economic crisis that led to the adoption of the USA dollar as the national currency and forced 
hundreds of thousands of families to migrate to Europe and the USA, breaking up important support networks. Among those who stayed in the country, the poorest and most disenfranchised were located in rural areas or marginalised urban communities.

In parallel with problems of racial violence and exclusion, marginalisation from quality mental health care (based on income and race-ethnicity), was a legacy from the colonial period that continued in the $20^{\text {th }}$ century (Vega, 2012). It was not until the 1960s-1970s, that previous Latin American political revolutions inspired Ecuadorians to debate the sociocultural dimensions of health (Breilh, 2008). At times when the role of mental health professions was still confusing, attempts to promote a socially engaged mental health policy were frustrated by a "neoliberal agenda": a "breakdown of public health" (Breilh, 2008, p. 747) that cut funds and stagnated well intended professional efforts for more than two decades.

Today, the landscape has changed, as public policy is based - not without challenges (Lalander, 2014) - on the Good-Living ideal: human rights, equality, cultural diversity and ecological sustainability. Local mental health policy now advocates the incorporation of culture into care (Ministerio de Salud Pública, 2014). If this policy is to be successfully actualised, an understanding of the impact of history is unavoidable.

\section{Collective memory and historical trauma}

After centuries of structural and cultural violence, Ecuadorian mental health care is in a liminal state, shifting from historical neglect to State recognition. This liminality is observed in the way historical construction of class and race-ethnicity are addressed. A deep and nuanced discussion of such issues does not seem to be a priority among the local population (Beck et al., 2011), mental health professionals 
included. As illustrated in the vignette at the start of this paper, history might not be acknowledged by civil servants and academics when discussing the "culture of violence" within marginalised urban African-Ecuadorian communities. Why not? Have local communities and mental health professionals forgotten or silenced their violent past? In order to hypothesise further, it is first necessary to understand how collective memory and historical trauma operate.

The concept of collective memory has a long history, although it was Halbwachs (1992) who introduced the term in the context of early $20^{\text {th }}$ century sociology. At its core, the concept involves a process of dynamic collective remembering and forgetting of a shared past that reinforces social identity. Such a process is shaped by (inter) subjectivities, values, ideology, and rhetoric. Its mechanism is primarily cultural, involving socially and historically situated repertoires, as humans remember and forget "according to the memory frames and practices of the groups of which they are members" (Brockmeier, 2002, p. 23). Although used in diverse ways across disciplines, collective memory is intrinsically linked to the particular narrative, identity and culture of the specific groups where it is constructed (Wertsch \& Roediger, 2008).

Central to this notion is the concept of historical trauma. Preceded by critiques of the term trauma itself (Summerfield, 2001) - the current approach is to situate historical trauma not as an objectified causal factor, but as a context-bounded, heterogeneous, socially-shaped narrative (Mohatt, Thompson, Thai, \& Tebes, 2014). Thus, it refers to a particular language of distress which confronts colonial victimisation with individual agency and resilience (Waldram, 2014). This non-static conceptual approach prevents scholars and mental health professionals from making 
simplistic assumptions of inter-generational transmission of $a$ trauma within nonwhite families, and pathologising their suffering (Maxwell, 2014). Simultaneously, it emphasises how diagnosis around trauma "concerns history and the collective past, as well as moral responsibility, and not just individual, private, traumatic experience" (Beneduce, 2016, p. 275).

Several reasons might lead to the absence of a historical trauma narrative. Two crucial possibilities are highlighted. First, evoking painful memories can have high physical or emotional risks (Green, 1999). In this case, a sort of repression individual or collective - might operate as a coping mechanism. This could arguably, in certain contexts do more good than harm compared with recall and disclosure, especially if these are forced. Second, remembering past events can threaten the status quo (Zembylas \& Bekerman, 2008), leading to the silence of painful narratives (Littlewood, 2009) by “the architects of structural violence" (Farmer, 2004, p. 308). In Ecuador, for example, the creoles can be remembered for their fight for "freedom", or because of their perpetuation of local economic and racial oppression. The way history is constructed can result in individual and collective alienation and suffering, if uncritical views are promoted. The balance between useful repression and the need for empowering political awareness is clearly a dilemma to be tackled according to specific contexts, concerns and objectives.

History is recalled via heterogeneous strategies, either romanticizing or contetesting it (Lopez, Carretero, \& Rodriguez-Moneo, 2014), and is contructed through multiple inter-subjective processes (Hewer \& Roberts, 2012). In Chile, for example, indigenous groups share collectives memories about their origins, to preserve their values and identity (Aravena, 2014). In Bolivia, healers and activists 
place the concept of "loss" (.e.g., of soul; of identity) at the core of colonialism, linking the clinical with the cultural-political (Burman, 2010). In Argentina, college students rhetorically reconcile their pre-Hispanic origins with both colonial violence and the birth of a modern State (Carretero \& Kriger, 2011). In Ecuador, rural haciendas where the indigenous used to be abused are potentially rethought as commemorative spaces (Jamieson, 2014), while African-Ecuadorian written and oral resistance aims at contesting a complex, asymmetrical historical relationship with the State (Walsh \& Salazar, 2015). In her study of race, gender and capital within markets in the Ecuadorian Andes, Weismantel (2001) illustrates how a colonial past is pervasively embodied in contemporary myths, practices and interactions.

The way through which contemporary political violence in Latin America is remembered illustrates how history is evoked. There are local debates around how to remember the systematic murders and torture by both military-dictatorships - e.g., Argentina (Kaiser, 2015); Chile (Piper-Shafir, Fernández-Droguett, \& Iñiguez-Rueda, 2013); and Uruguay (Draper, 2012) - and insurgency-counterinsurgency warfare - e.g. Peru (Chauca-Sabroso \& Fuentes-Polar, 2013; Theidon, 2013); Guatemala (Green, 1999). Green's ethnography, for example, illustrates how lived violence can penetrate community's "social memory" (p.55), generating fear and distrust, and silencing the past through forcibly eliciting narratives of fear-induced ill-states such as susto.

This leads us to a final conceptual claim, before addressing the Ecuadorian case: collective memory and historical trauma provide a cultural alternative to orthodox biomedical or psychological theories of suffering. In the case of Ecuador, we argue that a distant colonial ethos; a modern Eurocentric racism; and more contemporary structural-cultural violence shaped local identities and memory frames, 
not necessarily via immediate, social categorisation, but through the embodiment of historical power relationships in the form of habitus (Bourdieu, 1990). A habitus is a learned schemata of thought and action that enables cultural reproduction, shaped by the social groups where subjects were socialised, and their historical struggle for material, symbolic and cultural capital in diverse fields.

To answer a key question posed in this paper: Why do Ecuadorians may not be discussing their violent history? - two non-exclusive hypotheses emerge. The first focuses on forgetfulness as a coping mechanism. Professionals and communities might find it uncomfortable to openly address post-colonial feelings of alienation, disvalue, anger, conformity or dependency (DuBois, 1903; Fanon, 2004; Freire, 1970), and to disclose the historical origins of their cultural identities, especially if these are disvalued (Goffman, 1990). The second is concerned with ideology: the local and global architects of structural violence promote the de-historicising and de-politicising of suffering. Examples of such ideological processes are the mestizaje discourse, or the romantic myth of Guayaquil city as an "open port" with equal opportunities for all (Roitman, 2009), leading to a "rejection of the city's problematic articulation of racial oppression, patriarchal structures, homophobic and heterosexist behaviour, and exploitative class conditions" (Benavides, 2006, p. 61).

Of course, these, and other hypotheses around Ecuadorian collective memory and historical trauma narratives require further research, and the generation of new questions. For example: A few centuries ago (1546), - after a shipwreck near what today is the Esmeraldas province - African-descendants allied with local indigenous people in a remarkable community that used violence to fiercely resist colonising intrusions into their territory (Bryant, 2004); Do contemporary non-white ethnicities 
remember these events? What about the white-looking mestizo or the white minority? Could modern violence at the margins be - to some extent - a sort of reproduction of anticolonial resistance? Is it possible, reasonable and desirable to unpack the way a collective traumatic history is transformed into subjective symptoms (Beneduce, 2016), such as hallucinations; substance abuse; or experiences and expressions of violence? As much needed as this research is, a different type of concern is expected to be raised among practicing professionals: How can historical consciousness be incorporated into mental health theory and interventions in Ecuador? The following section addresses this question, by situating it within the context of international literature.

\section{Historically informed mental health interventions: Lessons from other latitudes}

Integrating history and violence into mental health theory and practice is a political process (Prussing, 2014), that demands careful "attention to the social ecology of history, trauma, and identity for a given population" (Mohatt et al., 2014, p. 134). Remembering can be discouraged by subject's legitimate fears and resistances (Green, 1999), or by bio-medically-oriented institutions that de-historicise suffering (Beneduce, 2016). Recovering historical memory through mental health interventions has shown to promote both healing and political empowerment of historically oppressed individuals and communities, among indigenous groups in New Zealand (Lawson-Te Aho, 2014); and North America (Hartmann \& Gone, 2014). It is possible that historically informed interventions do not necessarily lead to a process of "recovery" per se - as understood from an orthodox biomedical standpoint -, but one 
of "living on," finding a sense in history to experience a meaningful transformation (Lloyd, 2000).

The objectives of public mental health interventions will vary according to particular contexts and concerns. Three potential goals could be postulated: I. Promote community identity, local values and political empowerment (McLeigh, 2010); II. Facilitate inter-generational dialogues and engage children and young people with historical narratives (Habashi, 2013); III. Vindicate (e.g. incorporate into available services) healing practices (e.g. indigenous rituals) that have been historically marginalised (Gone, 2014). It might be recommendable to focus interventions on strengths and resilience rather than pain, as stressed by Brave Heart, Chase, Elkins, \& Altschul, (2011). These, and others authors (Goodkind et al., 2010) also suggest the importance of a formal apology by the State for the historical institutionalization of violence.

The methods for implementing interventions are also expected to vary based on contexts and concerns, not to mention the skills and approach of the professionals in charge. These can include, among others: I. Culturally sensitive clinical interventions - e.g. Work with African migrants in Italy (Beneduce, 2016)- II. Workshops - e.g., Latin American tradition of "liberation" community psychology (Chauca-Sabroso \& Fuentes-Polar, 2013); sociodramatic approaches (Bello, 2004); III. Art - e.g. graphic art and hip-hop in North America (Crawford, 2014; Sheffield, 2004); multimedia-exhibits in Korea (Liem, 2007); films in Argentina (Peller, 2009) or in Ecuador (Ruggiero, 2015); and murals in Northern Ireland (McDermott, Nic Craith, \& Strani, 2015); IV. Commemorative expressions in traditional and online media platforms - e.g. Argentinians "militants of memory" commemorating victims of 
military repression (Benegas Loyo, D’Alessio, \& Colosimo, 2014); obituaries during the civil rights movement in the USA (McElroy, 2013); V. Visits and collaborations to museums and archives - e.g the "Center for Popular Memory" in South Africa (Meyer, 2008). VI. Political activism - e.g. unpacking the legacies of slavery by the French Empire (Fleming, 2012). Although these methods can be used to address any historical event, we stress their importance to deal with a remarkably influential colonial past, which might tend to be overlooked.

Mental health initiatives of this kind seem to be rare in Ecuador. To mention a case from a different health field (maternal care), there is a registered incorporation of indigenous health practices into available services, with users being given the option to receive care that is professional, traditional or both (Torri, 2013). In the mental health field, there are records of well-intended collaboration between Ecuadorian psychiatrists and traditional healers in diagnoses (Incayawar, 2008), although within a framework of global mental health which has been criticised for imposing western concepts and ignoring local influences on distress and wellbeing (Fernando, 2014). The road for incorporating history into mental health interventions - and disseminating such experiences - is still to be constructed, and - inspiration from other latitudes aside - Ecuador need to find ways of advancing this endeavour on its own terms.

However, criticism of such intervention suggests they could revive historical wounds and outdated categories, while perpetuating the resentments of "colonised minds" through linking contemporary identities with former European colonisers (Sen, 2006). Moreover, a disproportionate emphasis on history can, paradoxically, divert attention from present-day sources of inequalities and violence. To avoid these 
problems, the past must be contextualised and anchored within modern experiences of suffering (Kirmayer et al., 2014).

The recovery of historical memory requires consideration of several diverse means, such as: an adequate policy framework (McLeigh, 2010); truth committees (Comisión de la Verdad, 2010); or formal gestures, such as the Pope's recent apologies (Winfield \& Garcia, 2015). For researchers and mental health professionals, it demands addressing historical and cultural influences on health (Napier et al., 2014); local ecologies of suffering (Jadhav, Jain, Kannuri, Bayetti, \& Barua, 2015); and local cultural histories (Burke, 2012), an agenda that requires a transdisciplinary approach. Healing interventions need, of course, to focus on forgiveness -e.g. Israel-Palestine (McKnight, 2004) - although avoiding the risks of a top-down approach which would be violent itself - e.g. Peru (Theidon, 2013). If done in a both therapeutic and empowering manner, the process may allow descendants of victims and perpetrators to build a historical narrative that leads to awareness and potential reconciliation.

History should play an important role in the training of mental health professionals. The vignette cited at the start of this paper raised critical questions about the role of history in contemporary mental health interventions, in this case, in a marginalized urban community. Mental health professionals and State representatives need to discuss the histories of such communities, in order to efficiently analyse violence and design interventions. Contemporary "cultures of violence" do not exist in a historical vacuum. These are the product of centuries of power asymmetries and the use of material and symbolic coercion, mainly affecting low-income, non-white ethnicities, with women being particularly vulnerable. 
History will obviously fall short in explaining present contingencies around violent episodes. Clearly, other levels of analysis would be necessary. For example, to address violence as lived by Ecuadorian youth gangs (Cerbino, 2012) and women (Consejo Nacional para la Igualdad de Género, 2014). Still, history provides a fundamental level of analysis associated with post-colonial cultural reproduction, embodied in ways that range from poverty, addiction, rape or murders, to less "spectacular" violence, such as racist and sexist jokes made by State representatives and mental health professionals. These violent social practices have their own historical-cultural development, which needs to be critically examined. A pivotal field for advancing such agenda is education (Freire, 1970). Professional training needs to critically engage with history, which requires "listening to the voice of the defeated" (Mininni, Manuti, \& Curigliano, 2013, p. 55), and linking research and practice with such voice. Doing so will open engaging and crucial lines of inquiry and action for historians, social scientists and mental health professionals.

Historically informed initiatives, we argue, should not only be aimed for indigenous or African-descendant groups, but for all Ecuadorians, including mental health professionals and their academic theory. In view of recent progressive policy initiatives on mental health in Ecuador (Ministerio de Salud Pública, 2014), it is timely for local professionals and communities with diverse cultural backgrounds to seriously engage with their histories and their present implications.

\section{Conclusion}

As illustrated throughout this paper, history matters for mental health research and practice. The recovery of historical memory emerges as an important task for professionals and policy-makers. A nuanced examination of history will contribute to 
a mental health practice that avoids de-historization and de-politicisation. In this paper, the authors have relied on key concepts of collective memory and narratives of historical trauma, in order to outline their role in Ecuadorian mental health. Far from definitive, the paper aims to engage local mental health professionals, policy-makers and communities with the crucial relevance of history, as necessary for both theory and interventions. Insights derived from such research may contribute towards ongoing international discussions on violence, colonialism and mental health, particularly in postcolonial nations worldwide. Only after examining our past, we will be able to make full use of our agency to transform our present.

\section{Acknowledgement}

The authors wish to thank Maan Barua, David Goldberg and Alfred Hinrichsen for their comments on earlier drafts.

\section{Funding}

MC as awarded a PhD grant by the Ecuadorian National Secretary of Higher Education, Science, Technology and Innovation - SENESCYT, with funds managed by the Institute for the Promotion of Human Talent (formerly the Ecuadorian Institute for Educational Loans and Grants - IECE).

\section{References}

Aravena, A. (2014). El rol de la memoria colectiva y de la memoria individual en la conversion identitaria mapuche [The role of collective and individual memory in the mapuche identity conversion]. Estudios Atacameños, 26(26), 89-96.

Austin Alchon, S. (1992). Native Society and Disease in Colonial Ecuador. Cambridge: Cambridge University Press.

Ayala Mora, E. (2008). Resumen de historia del Ecuador [Summary of the Ecuadorian history]. Quito: Corporación Editora Nacional. Retrieved from http://repositorio.uasb.edu.ec/bitstream/10644/836/1/AYALAE-CON0001RESUMEN.pdf

Beck, S. H., Mijeski, K. J., \& Stark, M. M. (2011). Qué es racismo? Awareness of racism and 
discrimination in Ecuador. Latin American Research Review, 46(1), 102-125.

Bello, M. C. (2004). Primer sociodrama público y simultáneo en América Latina: Escenas de los pueblos [First public and simultaneous sociodrama in Latin America: Scenes of the people]. Mexico D.F.: Centro de Investigaciones Interdisciplinarias en Ciencias y Humanidades.

Benavides, O. H. (2002). The representation of Guayaquil's sexual past: Historicizing the enchaquirados. Journal of Latin American Anthropology, 7(1), 68-103.

Benavides, O. H. (2006). The politics of sentiment: Imagining and remembering Guayaquil. Austin: University of Oklahoma Press.

Beneduce, R. (2016). Traumatic pasts and the historical imagination: Symptoms of loss, postcolonial suffering, and counter-memories among African migrants. Transcultural Psychiatry, 53(3), 261-285. http://doi.org/10.1177/1363461516645079

Benegas Loyo, D., D'Alessio, A., \& Colosimo, A. (2014). "Hoy cumplirías años": Recordatorios en los diarios, tácticas de afecto y memoria en la esfera pública postdictadura ["Today would be your birthday": Reminders in newespapers, tactics of affect and memory in the post-dictatorship public sphere]. Athenea Digital, 14(2), 147169.

Borchart de moreno, C. (2004). Words and wounds: Gender relations, violence, and the state in late colonial and early republican Ecuador. Colonial Latin American Review, 13(1), 129-144.

Bourdieu, P. (1990). The logic of practice. Cambridge: Pollity Press.

Brave Heart, M. Y. H., Chase, J., Elkins, J., \& Altschul, D. B. (2011). Historical trauma among indigenous peoples of the Americas: Concepts, research, and clinical considerations. Journal of Psychoactive Drugs, 43(4), 282-290.

Breilh, J. (2008). Latin American critical ('Social') epidemiology: New settings for an old dream. International Journal of Epidemiology, 37, 745-750.

Brockmeier, J. (2002). Remembering and forgetting: Narrative as cultural memory. Culture \& Psychology, 8(1), 15-43.

Bryant, S. K. (2004). Enslaved rebels, fugitives, and litigants: The resistance continuum in colonial Quito. Colonial Latin American Review, 13(1), 7-46.

Burke, P. (2012). Strengths and weaknesses of cultural history. Cultural History, 1(1), 1-13.

Burman, A. (2010). The strange and the native: Ritual and activism in the aymara quest for decolonization. Journal of Latin American and Caribbean Anthropology, 15(2), 457475. http://doi.org/10.1111/j.1935-4940.2010.01094.x

Carretero, M., \& Kriger, M. (2011). Historical representations and conflicts about indigenous people as national identities. Culture \& Psychology, 17(2), 177-195.

Cerbino, M. (2012). El lugar de la violencia. Perspectivas críticas sobre pandillerismo juvenil [The place of violene. Critical perspectives on juvenile gangs]. Quito: Taurus FLACSO.

Chauca-Sabroso, R., \& Fuentes-Polar, S. (2013). Development of historical memory as a psychosocial recovery process. In M. Montero \& C. C. Sonn (Eds.), Psychology of liberation: Theory and applications. (pp. 205-220). New York: Springer.

Chaves, M. E. (2001). Honor y libertad: Discursos y recursos en la estrategia de libertad de una mujer esclava (Guayaquil a fines del periodo colonial) [Honor and freedom: Discourses and resources in the strategy for freedom of an slaved woman (Guayaquil at the end of the colonial period)]. University of Gotemburg.

Chopik, W. J., O’Brien, E., \& Konrath, S. H. (2016). Differences in empathic concern and perspective taking across 63 countries. Journal of Cross-Cultural Psychology, October, 1-16. http://doi.org/10.1177/0022022116673910 
Comisión de la Verdad. (2010). Informe de la Comisión de la Verdad [Truth Comission report].

Quito.

Retrieved

from

http://www.alfonsozambrano.com/comision_verdad/cdv10-informe_final.pdf

Conferencia Episcopal Ecuatoriana. (2001). Historia de la iglesia católica en el Ecuador Vol.2 [History of the Catholic Church in Ecuador vol 2]. Quito: Abya - Yala.

Consejo Nacional para la Igualdad de Género. (2014). La violencia de género contra las mujeres en el Ecuador: Análisis de los resultados de la Encuesta Nacional sobre Relaciones Familiares y Violencia de Género contra las Mujeres [Gendered violence against women in Ecuador: Analysis of the results of the national survey on family relationship and gendered violence against women]. Quito.

Constitución de la República del Ecuador [const] (2008). Registro official No449. (2008). Retrieved from http://www.administracionpublica.gob.ec/wpcontent/uploads/downloads/2014/10/Constituci\%C3\%B3n-de-la-Rep\%C3\%BAblica-delEcuador.pdf

Crawford, A. (2014). "The trauma experienced by generations past having an effect in their descendants": Narrative and historical trauma among Inuit in Nunavut, Canada. Transcultural Psychiatry, 51(3), 339-369.

Cruza-Guet, M.-C., Spokane, A. R., Leon-Andrade, C., \& Borja, T. (2009). Diversity, hegemony, poverty, and the emergence of counseling psychology in Ecuador. In L. Gerstein; P.Heppner, S.AEgisdóttir; S. Alvin; and K. Norswhorthy (Eds.), International handbook of cross-cultural counseling: Cultural assumptions and practices worldwide (pp. 393-401). Thousand Oaks, CA, US: Sage.

Czyzewski, K. (2011). Colonialism as a broader social determinant of health. The International Indigenous Policy Journal, 2(1), 1-14.

Draper, S. (2012). Making the past perceptible: Reflections on the temporal and visual enframings of violence in the Museum of Memory in Uruguay. Journal of Educational Media, Memory, and Society, 4(2), 94-111. http://doi.org/10.3167/jemms.2012.040206

DuBois, W. E. B. (1903). The Souls of black folk. New York: Barnes \& Noble Books.

Fanon, F. (2004). The wretched of the earth. New York: Grove Press.

Farmer, P. (2004). An anthropology of structural violence. Current Anthropology, 45(3), 305325.

Fernando, S. (2014). Globalization of psychiatry: A barrier to mental health development. International Review of Psychiatry, 26(5), 551-557.

Fleming, C. M. (2012). White cruelty or Republican sins? Competing frames of stigma reversal in French commemorations of slavery. Ethnic and Racial Studies, 35(3), 488505.

Freire, P. (1970). Pedagogy of the opressed. New York: Herder and Herder.

Galtung, J. (2003). Violencia cultural [Cultural violence]. Bilbao: Gernika-Lumo/Gernika Gogoratuz.

Garcilaso de la Vega, I. (1963). Comentarios reales de los incas, 1539 - 1616 [Inca royal commentaries]. Montevideo: Ministerio de Instrucción Pública y Previsión Social.

Goffman, E. (1990). Stigma: Notes on the management of spoiled identity. London: Penguin.

Gone, J. P. (2014). Redressing First Nations historical trauma: Theorizing mechanisms for indigenous culture as mental health treatment. Transcultural Psychiatry, 50(5), 683-706.

Goodkind, J. R., Ross-Toledo, K., John, S., Hall, J. L., Ross, L., Freeland, L., ... Lee, C. (2010). Promoting healing and restoring trust: Policy recommendations for improving behavioral health care for American Indian/Alaska Native adolescents. American Journal of Community Psychology, 46(3), 386-394.

Green, L. (1999). Fear as a way of life: Mayan widows in rural Guatemala. New York: 
Columbia University Press.

Habashi, J. (2013). Palestinian children: Authors of collective memory. Children and Society, 27(6), 421-433.

Halbwachs, M. (1992). On collective memory. Chicago, London: University of Chicago Press.

Hartmann, W. E., \& Gone, J. P. (2014). American Indian historical trauma: Community perspectives from two Great Plains medicine men. American Journal of Community Psychology, 54(3-4), 274-288.

Hewer, C. J., \& Roberts, R. (2012). History, culture and cognition: Towards a dynamic model of social memory. Culture \& Psychology, 18(2), 167-183.

Ibarra, H. (1992). La identidad devaluada de los Modern Indians [The disvalued identity of Modern Indians]. In D. Cornejo (Ed.), Indios: Una reflexión sobre el lenvantamiento indígena de 1990 (pp. 319-350). Quito: Instituto Latinoamericano de Investigaciones Sociales.

Incayawar, M. (2008). Efficacy of Quichua healers as psychiatric diagnosticians. The British Journal of Psychiatry, 192(5), 390-391.

Jadhav, S. (1996). The cultural origins of western depression. International Journal of Social Psychiatry, 42(4), 269-286.

Jadhav, S., Jain, S., Kannuri, N., Bayetti, C., \& Barua, M. (2015). Ecologies of Suffering. Mental Health in India. Economic and Political Weekly, L(20).

Jamieson, R. W. (2014). Hacienda ruins as sites of difficult memory in Chimborazo, Ecuador. Journal of Social Archaeology, 14(2), 224-243. http://doi.org/10.1177/1469605314521275

Kaiser, S. (2015). Argentina's Trials: New ways of writing memory. Latin American Perspectives, 42(3), 193-206. http://doi.org/10.1177/0094582X15570885

Kirmayer, L. J., Gone, J. P., \& Moses, J. (2014). Rethinking historical trauma. Transcultural Psychiatry, 51(3), 299-319.

Lalander, R. (2014). The Ecuadorian resource dilemma: Sumak Kawsay or development? Critical Sociology, 1-20.

Lane, K. (2003). Haunting the present: Five colonial legacies for the new millenium. In N. E. Whitten Jr. (Ed.), Millenial Ecuador: Critical essays on cultural transformation \& social dynamics (pp. 75-101). Iowa: University of Iowa Press.

Lawson-Te Aho, K. (2014). The healing is in the pain: Revisiting and re-narrating trauma histories as a starting point for healing. Psychology \& Developing Societies, 26(2), 181212.

Liem, R. (2007). Silencing historical trauma: The politics and psychology of memory and voice. Peace and Conflict: Journal of Peace Psychology, 13(2), 153-174.

Linke, L. (1954). Ecuador, country of contrasts. London: Oxford University Press.

Littlewood, R. (2009). Neglect as project: How two societies forget. Journal of the Royal Anthropological Institute, 15(1), 113-130.

Lloyd, D. (2000). Colonial trauma/postcolonial recovery? Interventions, 2(2), 212-228.

Lopez, C., Carretero, M., \& Rodriguez-Moneo, M. (2014). Telling a national narrative that is not your own. Does it enable critical historical consumption? Culture \& Psychology, 20(4), 547-571.

Mari, J. D. J., Saraceno, B., Rodriguez, J., \& Levav, I. (2007). Mental health systems in Latin America and Caribbean countries: A change in the making. Psychological Medicine, 37(10), 1514-1516.

Marx, K. (1977). Capital, volume 1. London: Lawrence \& Wishart.

Maxwell, K. (2014). Historicizing historical trauma theory: Troubling the trans-generational transmission paradigm. Transcultural Psychiatry, 51(3), 407-435. Retrieved from 
http://www.ncbi.nlm.nih.gov/pubmed/24855143

McDermott, P., Nic Craith, M., \& Strani, K. (2015). Public space, collective memory and intercultural dialogue in a (UK) city of culture. Identities: Global Studies in Culture and Power, 1-18.

McElroy, K. (2013). You must remember this: Obituaries and the civil rights movement. Journal of Black Studies, 44(4), 335-355.

McEwan, C., \& Delgado, F. (2008). Late pre-Hispanic polities of coastal Ecuador. In H. Silverman \& W. H. Isbell (Eds.), Handbook of South American archaeology (505-526). New York: Springer.

McKnight, A. N. (2004). Historical trauma, the persistence of memory and the pedagogical problems of forgiveness, justice and peace. Educational Studies, 36(2), 140-158.

McLeigh, J. D. (2010). What are the policy issues related to the mental health of Native Americans? The American Journal of Orthopsychiatry, 80(2), 177-182.

Meyer, R. (2008). What lies below: Exploring constructions of collective memory in archival collections. South African Historical Journal, 60(2), 209-225.

Milton, C. E. (2004). Wandering waifs and abandoned babes: The limits and uses of juvenile welfare in eighteenth-century audiencia of Quito. Colonial Latin American Review, 13(1), 103-128.

Mininni, G., Manuti, A., \& Curigliano, G. (2013). Commemorative acts as discursive resources of historical identity. Culture \& Psychology, 19(1), 33-59.

Ministerio de Salud Pública. (2014). Plan Estratégico Nacional de Salud Mental 2014 - 20171 [Strategic National Plan for Mental Health 2014 - 2017]. Quito.

Mohatt, N. V., Thompson, A. B., Thai, N. D., \& Tebes, J. K. (2014). Historical trauma as public narrative: A conceptual review of how history impacts present-day health. Social Science and Medicine, 106, 128-136.

Moreno, F. (2009). Violencia colectiva, violencia política, violencia social. Aproximaciones conceptuales [Collective violence, political violence, social violence. Conceptual approximations]. In I. Markez, A. Fernández-Liria, \& P. Pérez-Sales (Eds.), Violencia y salud mental. Salud mental y violencias institucional, estructural, social y colectiva (pp. 19-36). Madrid: Asociación Española de Neuropsiquiatría.

Moser, C. O. N. (2009). Ordinary families, extraordinary lives. Assets and poverty reduction in Guayaquil, 1978 - 2004. Washington, D.C.: Brrokings Institution Press.

Napier, A. D., Ancarno, C., Butler, B., Calabrese, J., Chater, A., Chatterjee, H., ... Woolf, K. (2014). Culture and health. The Lancet, 384(9954), 1607-39.

Newson, L. (1995). Life and death in early colonial Ecuador. Norman, London: University of Oklahoma Press.

Peller, M. (2009). Memoría, historia y subjetividad. Notas sobre un film argentino contemporáneo [Memory, history and subjectivity. Notes on an contemporary Argentinian film]. Política Y Cultura, (31), 49-63.

Penson, W. J. (2014). Psy-science and the colonial relationship in the mental health field. Mental Health Review Journal, 19(3), 176-184.

Piper-Shafir, I., Fernández-Droguett, R., \& Iñiguez-Rueda, L. (2013). Psicología social de la memoria: espacios y políticas del recuerdo [Social psychology of memory: Spaces and politics of remembering]. Psykhe (Santiago), 22(2), 19-31. http://doi.org/10.7764/psykhe.22.2.574

Powers, K. V. (2002). Conquering discourses of "sexual conquest": Of women, language, and mestizaje. Colonial Latin American Review, 11(1), 7-32.

Prussing, E. (2014). Historical trauma: Politics of a conceptual framework. Transcultural Psychiatry, 51(3), 436-458. 
Roitman, K. (2009). Race, ethnicity and power in Ecuador. London: First Forum Press.

Ruggiero, D. M. (2015). Más allá del fútbol: Teaching highland Afro-Ecuadorian culture and engaging race and racism through documentary film. Hispania, 98(3), 594-606.

Salomon, F. (1983). Shamanism and politics in late-colonial Ecuador. American Ethnologist, 10(3), 413-428. http://doi.org/10.1525/ae.1983.10.3.02a00010

Sen, A. (2006). Identity and violence: the illusion of destiny. New York: W.W. Norton \& Company.

Sheffield, C. L. (2004). Native American hip-hop and historical trauma. Studies in American Indian Literatures, 15(3), 94-110.

Silverblatt, I. (1983). The evolution of witchcraft and the meaning of healing in colonial Andean society. Culture, Medicine and Psychiatry, 7, 413-427.

Stahl, P. W. (1986). Hallucinatory imagery and the origin of early South American figurine art. World Archaeology, 18(1), 134-150.

Stewart, P. J., \& Strathern, A. (2002). Violence as a construct. In P. J. Stewart \& A. Strathern (Eds.), Violence: Theory and ethnography (pp. 1-14). London, New York: Continuum.

Summerfield, D. (2001). The invention of post-traumatic stress disorder and the social usefulness of a psychiatric category. British Medical Journal, 322(7278), 95-98.

Theidon, K. S. (2013). Intimate enemies : Violence and reconciliation in Peru. Philadelphia: University of Pennsylvania Press.

Torri, M. C. (2013). Choosing between traditional medicine and allopathy during pregnancy: Health practices in prenatal and reproductive health care in Ecuador. Journal of Health Management, 15(3), 397-413.

Townsend, C. (2000). Tales of two cities: Race and economic culture in early republican North and South America: Guayaquil, Ecuador, and Baltimore, Maryland. Texas: University of Texas Press.

Ubelaker, D. H. (2003). Health issues in the early formative of Ecuador: Skeletal biology of Real Alto. In J. S. J. Scott Raymond \& R. L. Burger (Eds.), Archaeology of Formative Ecuador (pp. 259-287). Washington, D.C.: Dumbarton Oaks Research Library and Collection.

Vega, G. (2012). Historia y psiquiatría (fascículos 1 - 5) [History and psychiatry. Fascicles 1-5]. Quito: Universidad Internacional del Ecuador.

Waldram, J. B. (2014). Healing history? Aboriginal healing, historical trauma, and personal responsibility, 51(3), 370-386.

Walsh, C., \& Salazar, J. G. (2015). Memoria colectiva, escritura y Estado. Prácticas pedagógicas de existencia afroecuatoriana [Collective memory, writting and the State. Pedagogic practices of afroecuadorian existence]. Cuadernos de Literatura, 19(38), 7998. http://doi.org/10.11144/Javeriana.cl19-38.mcee

Weismantel, M. (2001). Cholas and pishtacos: Stories of race and sex in the Andes. Chicago, London: University of Chicago Press.

Wertsch, J. V, \& Roediger, H. L. (2008). Collective memory: Conceptual foundations and theoretical approaches. Memory, 16(3), 318-326.

Winfield, N., \& Garcia, J. (2015). Pope Apologizes For Catholic Church's "Offenses" Against Indigenous Peoples. The Huffington Post. Retrieved from http://www.huffingtonpost.com/entry/pope-francis-apologizes-for-catholic-churchsoffenses-against-indigenous-peoples_559f02aae4b096729155dd59

Young, R. (1995). Colonial desire: Hybridity in theory, culture and race. London: Routledge.

Zembylas, M., \& Bekerman, Z. (2008). Education and the dangerous memories of historical trauma: Narratives of pain, narratives of hope. Curriculum Inquiry, 38(2), 125-154. 


\section{Notes}

' Updated and comprehensive epidemiological mental health data in Ecuador is relatively limited at the moment, according to the current Strategic National Mental Health Plan.

${ }^{\text {ii }}$ Just as in this case, a few other citations from Spanish-language sources have been translated into English by MC. Based on official APA guidelines, these translations are not written between quotation marks, even though they are direct quotations (http://blog.apastyle.org/apastyle/2014/11/lost-in-translation-citing-yourown-translations-in-apa-style.html).

iii In the Latin American context, the term "Indian" is a synonym for "Indigenous". memory

iv The year of a contemporary publication of Halbwachs's On collective

${ }^{v}$ Thus, this paper is not a complete review of the vast literature and current debates on Latin American history, including its racial, economic, and gendered relationships. Rather, its focus is on the importance of history for the mental health field.

${ }^{\text {vi }}$ The year in which Quito was founded.

${ }^{\text {vii }}$ The Inca was the largest Pre- Hispanic American empire

viii In addition, mix-raced descendants of white and black origins were mulatos, and those of black and indigenous origins were zambos. Such categories are not commonly used in contemporary Ecuador. Today, the label mestizo implies a mix of any white and non-white ethnicity.

${ }^{\text {ix }}$ Under circumstances not necessarily or exclusively related to his class or race-ethnicity. 